\title{
Pattern of Agricultural Development in Southern Parts of Katsina State, Nigeria: Notion for Rational Planning
}

\author{
J. O. Adefila \\ (Phd) Senior Lecturer Department Of Geography Ahmadu Bello University Zaria, Nigeria
}

\begin{abstract}
Environmental contrasts in terms of climate, soil, vegetation, and natural endowments coupled with other processes at work often produce differing levels of development. While some areas are privileged, other areas may be lagging behind in some attributes. The study aimed at assessing the level of agricultural development in southern parts of Katsina State. It adopted a multi-stage sampling technique to obtain 200 samples among the seasoned farmers. The questionnaire was a major research instrument. A descriptive statistics was adopted to summarize the data. In addition, standardized score (Z-score) technique was employed to assess level of agricultural development. The study revealed that six out of the ten local government areas (LGAs) selected for the study are advantaged while the remaining four areas are disadvantaged. Bakori area enjoyed maximum benefits from the facilities with a score value of (8.47), followed by Funtua (7.39), Sabuwa (7.17), Malunfashi (6.09), Kankara (4.25), and Dandume (2.49) in that descending order of performance. These areas are categorized into upper third and middle third respectively. Also, the following areas suffered different shades of disadvantages namely, Ijusawa (-4.81), Danja (-3.16), Fasakari (-3.96), and Fafur (-4.08) and they are categorized as bottom third. The study area experiences differing levels of deprivation in agricultural development. The major constraints to agricultural development include high cost of agro-chemical which accounts for (21.0\%), nefarious activities of the middle-men (24.0\%), shortage of farm labour (15.0\%), and poor storage facilities (15.0\%). On the basis of the findings one recommends among other things that government needs to actively promote the establishment of agro-based industries that are capable of processing agricultural raw-materials in order to reduce wastes arising from poor storage facilities. There should be distributive justice in the allocation of resources in favour of lagging areas in order to have a balanced agricultural development over space.
\end{abstract}

Key Words: Agricultural Development Pattern Planning Spatial

\section{Introduction}

In spite of the increased significance of oil and gas sector, Nigeria largely remained an agrarian economy since a high percentage of the labour force continues to engage in agricultural production. The sector remains labour intensive and this explains in part the reason for down-ward trend in productivity. At independence, sector accounted for about 60 percent of the GDP but it declined sharply during the mid-1970s due to the growth of the mining and industrial sector as well as changes in government policies [1]. The growth of agricultural sector during the period of the so-called 'oil-boom' marked the beginning of down-turn and a serious stagnation in food and cash crop production [2]. The domestic food production reached a marginal level such that supply had to be augmented through importation of food items such as rice, wheat, sugar, milk and vegetable oils [3].

The British colonial administration had profound influence on the pattern of agricultural development in Nigeria by regionalizing department of agriculture along with the Federal Constitution in 1956. It placed much emphasis on research and extension services at a regional level with the establishment of a botanical research station in Lagos (1893); cotton plantation in Ibadan (1912), rice cultivation in Sokoto, Niger, Ilorin, Abeokuta and Ondo provinces. There was introduction of wheat cultivation in the northern parts of Nigeria and made arrangements for the establishment of irrigation schemes in the northern parts of Nigeria [4]. Besides, there was monetization of the economy by introducing cash rewards in exchange of goods and services. It introduced industrial cash crops such as cocoa, palm-produce, rubber and ground-nut. Each cash crop has a Marketing Board that oversees the preparation of the crops for export trade.

Moreover, the ecological zones in the country help to polarize the different types of crops being cultivated in Nigeria. For instance, the climate in the south favours cultivation of tree crops such as cocoa, palmproduce, rubber, and kola-nut within the forest belt while grain crops such as maize, guinea-corn, ground-nut and millet are cultivated in the drier northern parts of the country [5].

The post-independence period witnessed extensive planning and regional competition in agricultural development in Nigeria. It has to do with modification and modernization of the existing traditional practices in agriculture noting the incapacitation of the sector to produce adequate food for the teeming population. However, the second national development plan (1970-74) emphasized the introduction of modern agricultural 
methods through farm settlements, cooperatives among producers and supply of farm implements. The witnessed establishment of specialized agricultural development schemes included farm settlements, national accelerated food production programme (NAFPP), Operation Feed the Nation launched in 1976, river basin and rural development authority (RBRD) in 1976, green revolution in 1980 and of recent is the World Bank-Funded in collaboration with Federal government, Agricultural Development Projects (ADP) [6].

Perhaps of all the programmes initiated to improve agricultural production in the country, the ADPs represented the major practical demonstration of an integrated approach to agricultural development in Nigeria. It started in Funtua, Gombe and Gusau in 1974, Ayangba and Lafia in 1977, Bida 1979, and Ilorin in 1980 [7]. In collaboration with the World Bank, the project has radiated to all states in the country including the Federal Capital Territory, Abuja. It has encouraged the establishment of agricultural research institutes and their extension research liaison services as in Agricultural Extension and Research Liaison Service (AERLS) at the Ahmadu Bello University, Zaria that was established in 1963.

It is against this backdrop that one finds it necessary to examine the spatial pattern of agricultural development in southern parts of Katsina State having gained first-hand experience in the agricultural development project since 1974 .

\section{The Study Area}

The study area covers the relatively wet southern parts in Katsina State of Nigeria. The local government areas include; Bakori, Dandume, Danja, Faskari, Funtua, Ijusawa, Kafur, Kankara, Malunfashi and Sabuwa. It is located between Latitude $11^{\circ} 05^{\prime}$ north of the Equator and Longitude $7^{\circ} 08^{\prime}$ east of the Green Wich Meridian. The study area is bounded in the north by Dan-Ijusa and Ijatazu local government areas, in the east by Kano State, in the west by Zamfara State and in the south by Kaduna State. The study area has been carefully selected for this study following the memory lane, Katsina State was part of the first set of agricultural development project (ADP) being established in the country.

The study area is part of the tropical intercontinental north where the annual rainfall ranges between 50 $\mathrm{cm}$ to $100 \mathrm{~cm}$. It enjoys some four months of rainfall and has some eight months of aridity. Also, the relative humidity is always low about 40 percent in January and rise to about 60 percent in July. There are two principal winds that govern the climate of the area namely, the Tropical Maritime air mass (Tm) and the Continental air mass (Tc) [8]. While the former air mass brings rain to the entire study area during the wet season, the latter air mass brings aridity, since it originates from the desert area it is always cold, dry and dusty locally known as harmattan wind [9]. Soils in this area are formed under condition of aridity and deposition of sand by the wind. The soils are fine sandy loam, relatively easy to cultivate with little leaching hence, it is generally good for cultivation of groundnuts, grains and cotton especially in Funtua where cotton ginneries plant was first established.

Both vegetation and soils are somehow related since they are affected by the climate, geology and relief of the area. The soil determines to a large extent the type of plants that grow and in like manner, the soil helps to enrich the plant cover. The study area shares some characteristics of a sudan type of savanna vegetation. The trees are scattered with poor grassland. Some of the tree species include shear-butter tree, locust bean and date palms.

Regarding peoples, the most predominant tribes are the Fulanis and Hausas. However, there are Yorubas, Igbos and other tribes occupying some pocket areas. The Fulanis are noted for their animal husbandry and do engage in seasonal migration with their cattle, goats, sheep and donkey. The Hausas also engage in animal rearing but mostly occupied with sedentary agriculture. The major crops grown by the farmers include maize, guinea-corn, millet, soya-beans and groundnuts at both commercial and subsistence levels [9]. In addition, horticulture is practised mostly along the main streams and rivers where vegetables like okro, tomatoes, onion, sugar-cane, lettuce and spinach are cultivated.

\section{Recent Studies In Agricultural Development In Nigeria}

The agricultural sector has the potential to be the industrial springboard from which economic development can take off. Essentially, agricultural activities are usually concentrated in the rural areas where there is a critical need for socio-economic transformation, and wealth redistribution [10]. At independence, agricultural sector largely remained engine of economic growth contributing some 54.7 percent to the gross domestic product (GDP). But after a decade with the emergence of oil and gas this giant agricultural sector ceased to be the prime mover of economic growth. Looking back, it is clear that the economy has not actually performed to its full potential particularly in the face of its rising population. In general, economic growth and population growth rates are very close that the margin cannot induce the required structural transformation and economic diversification. The Nigerian economy has grossly underperformed relative to her enormous resource endowment and her peer nations [1]. The Brazilian experience is, of course, a striking example of how agriculture can advance beyond its primary function of supplying food and fibre. The agricultural sector has the 
potential to shape the landscape, provide environmental benefits such as land conservation, guarantee the sustainable management of renewable natural resources, preserve biodiversity and contribute to the viability of many rural areas [11]. In fact, through its different spheres of activities at both the macro and micro levels, the agricultural sector is strategically positioned to have a high multiplier effect on any nation's quests for socioeconomic and industrial development. There is no doubt that a sustained agricultural growth has been highly instrumental to Brazil's rapid rural transformation, the empowerment of Brazilian peasants and the alleviation of abject poverty. Interestingly, the Nigerian economy could reasonably be described as an agricultural economy at least during the first decade after independence because agriculture served as the engine of growth of the overall economy [12]. The study on farmers' cooperatives in Gurara area of Niger State in Nigeria showed that cooperatives played significant roles in agricultural development of this country. Prominent among their roles include raising their meagre funds to form a pool of fund and make it available to members to buy farm inputs such as chemical fertilizers, seedlings, herbicides, insecticides and hiring of tractors at affordable costs [13].

From the above studies [11];[14]; [1] and [13] adequate attention has not been given to the spatial pattern of agricultural development in Katsina State in particular and Nigeria at large and that remains a gap in knowledge that this present study intends to fill.

\section{Aim And Objectives Of Study}

The cardinal aim of the study is to analyse the spatial pattern of agricultural development in the southern parts of Katsina State. However, the specific objectives are to:- (i) examine the socio-economic characteristics of the farmers in the study area (ii) assess the level of agricultural development (iii) make a comparative analysis of the pattern of agricultural development (iv) examine the challenges facing agricultural development in the study area.

\subsection{Data Selection}

\section{Methodology}

The indicators of agricultural development were carefully selected for the study area and they include:(I) hectares of land under cultivation (II) bags of fertilizer usage (III) years of farming experience (IV) number of persons employed on farm activities (V) hours spent on farm operations (VI) number of modern equipment employed in farming operations

(VII) income per annum.

\subsection{Sources of Data}

The study of this nature demands for large amount of data which were obtained from both primary and secondary sources. The primary sources of data include a structured questionnaire that addressed the aim and objectives of the study as well as the research problem. Also, focused group discussions were conducted among the farmers in the study area. Field observations were conducted within the study area too. The secondary data were collected in order to authenticate those data collected from the questionnaire survey. Documented materials were gathered from the Ministry of Agriculture and Rural development, Federal of Statistics, National bureau of statistics, journals and printed materials.

\subsection{Sample Size and Sampling Techniques}

The sample size was varied according to size of the population of each local government area. It ensures a proportionate representation of the share of the population thus, Bakori (18), Dandume (20), Danja (15), Faskari (14), Funtua (30), Ijusawa (22), Fafur (15), Kankara (16), Malunfashi (21) and Sabuwa (19) making a total of 200 samples for the study. One adopted a multi-stage sampling procedure. First, a purposive sampling technique was used to select the local government areas within the southern parts of Katsina State. Second, a random sampling technique was adopted to select the households that engage in agricultural practice in the study area. Third, in each household the head or the person who is the breadwinner of the house was selected as part of the sample.

\subsection{Methods of Data Analysis}

The study made use of descriptive statistics to summarize the data into tabular form, frequencies, mean, and percentages. In addition, a standardized score (Z-score) analytical technique was adopted to depict the pattern of agricultural development in the study area. It is simple, and elegant and widely used in various studies [3]; [15];[16]. This approach affords the opportunity to rank the unit areas in accordance with their performance in the agricultural development. It measures the relative departure of the individual observation from the 'mean' of observations usually expressed in comparative form. The score of each local administrative area in each of the variables is standardized into Z-scores by changing the scores into zero mean and unit standard of deviation. 
The zero mean is produced and forms the base line from which departure of scores of observation in particular variable was compared.

\section{Data Analysis And Discussion}

The study examined the socio-economic traits of the respondents and the result is presented in TABLE 1. The respondents that were within the age-group of $0-20$ years are $(21.5 \%)$ of the respondents. The age-group of 21-40 that could be regarded as able-bodied men constitute about (34.0\%) of the sampled population in the study area. In comparison, this is a good indicator for potential labour force in respect of agricultural development. The age-group of 41-60 constitutes some (28.0\%) while those over 60 years are about (16.5\%).

Considering the marital status of the respondents, those that married are about (40.0\%) of the sampled population and this is strictly followed by the widows representing some $(23.0 \%)$ who must have married at a time but lost their spouses. The respondents that are yet to marry are about (17.5\%) and the divorced individuals are about $(17.5 \%)$ of the sample.

The annual income of the farmers was examined. The study showed that some $(37.5 \%)$ of the farmers had annual income level of N151, 000 - 200,000, while (26.5\%) had income of about N101,000 - N150,000. In addition, (23.0\%) and (13.0\%) had annual incomes of N51,000 - N100,000 and N0 - 50,000 respectively. The incomes of the farmers range from N0 to N200, 000 annually. This is an indication that income earnings by the farmers' cooperatives are still meagre for meaningful agricultural development.

The experience in farming operations was examined in terms of years being spent on agricultural practices and it revealed variations in terms of length of experience. For instance, some (33.5\%) of them have obtained 21-30 years experience in farming while $(26.0 \%)$ and $(25.0 \%)$ of them acquired $51-40$ years and $11-$ 20 years experience in farming respectively. In addition, some $(15.5 \%)$ of the farmers have attained less than 10 years experience in farming. Indeed, experience goes along with skill acquisition which is fundamental to efficiency and effectiveness in any job operation. The result implies that most of the farmers have acquired reasonable years of experience in farming which can have spread effects on agricultural development. This result apparently corroborated with [17] that farming experience has significant role in agricultural development. It is essentially an indication that farmers with more experience would likely adopt innovative ideas and techniques that would enhance increase in agricultural productivity.

The level of educational training of the respondents was examined and it showed that majority have a minimum of primary education accounting for $(37.5 \%)$ of the sampled population. This is followed by secondary education with $(31.5 \%)$. The respondents with non-formal education constitute about $(22.5 \%)$ and quranic education about (8.5\%). The type of agricultural activities being practiced by the farmers showed that majority $(31.5 \%)$ of the respondents engaged in cultivation of crops, some $(20.0 \%)$ of them engaged in animal husbandry. In addition some (22.5\%) and (26.0\%) of them practiced mixed farming and horticulture respectively. [18] had rightly observed that level of training amounts to capacity building of farmers and it could have potential effect on the agricultural growth at least in the long-run. It is important that farmers should receive proper orientation and training for the agricultural operations.

\subsection{Analysis of Spatial Pattern of Agricultural Development}

The standardized score (Z-score) of the agricultural variables are presented in TABLE 2. It has ten columns while the first column presents the names of the local government areas (LGAs) selected for the study in Katsina State, the other seven columns numbered Z1 to Z7 gave the standardized scores of the variables. The last column showed the summation of Z-scores, known as composite scores and the last column presents the categorization of local government areas into three namely: upper third, middle third and bottom third according to performance in agricultural development.

A close examination of TABLE 2, it revealed that six out of the ten local government areas (LGAs) in selected for this study are advantaged while the remaining four areas are disadvantaged as far as agricultural development is concerned. The composite score values of the advantaged areas range from 2.49 to 8.47. While Dandume LGA enjoyed the least of the agricultural variables with a score of 2.49 , Bakori area enjoyed maximum benefits from the facilities with a score value of 8.47. Funtua area ranks second in order of privileges with a score of 7.39. Some of the other LGAs in the advantaged category include Sabuwa (7.17), Malunfashi (6.09), and Kankara (4.25) in that descending order of performance. The scores of Bakori, Sabuwa and Funtua areas are worth noting. For instance, their composite scores are in multiple folds when compared with other areas. The three LGAs are privileged in all the agricultural variables selected for this study.

At the other extreme, four areas suffered different shades of disadvantages. The composite scores of areas in this category range from -4.81 to -3.16 representing Ijusawa and Danja areas respectively. Some of the other areas under this disadvantaged category include Fasakari (-3.96), and Fafur (-4.08). It is observed that Malunfashi area was found to be under-privileged in duration in terms of hours spent on farming operations. A 
close examination at Table 1, it is obvious that some areas are under-privileged in two out of the seven variables and they are Kankara and Dandume LGAs. While Kankara is disadvantaged in hours spent on farming operations (-0.65) and adoption of modern equipment (-0.31), Dandume suffered from number of persons employed on farms (-0.25) and the use of modern equipment (-0.45) in that order of performance. The two areas are at disadvantaged in terms the adoption of modern farm equipment. The study area experiences differing levels of deprivation or under-privileges as far as agricultural development is concerned.

\subsection{Challenges Facing Agricultural Development}

There are varying degrees of challenges confronting the agricultural development in the study area and this is examined. The result is presented in TABLE 3. A glance, it becomes obvious that a major constraint to agricultural development in the study area is the rarity of and high cost of agro-chemical such as fertilizers, herbicides, insecticides, fungicides which accounts for about $(21.0 \%)$ of the sampled population. This problem is not unconnected with the nefarious activities of the middle-men $(24.0 \%)$ who act as intermediary between manufacturer of agro-chemicals and the final consumers- the farmers at the rural communities. For instance, a bag of fertilizer is sold for \#2,000 per bag at controlled price from government but it often gets to the farmer at the village at about \#5,000 per bag which is beyond the reach of poor farmer [19]. The resultant effect is low agricultural productivity.

Parallel to above is the problem of shortage of farm labour which accounts for about $(15.0 \%)$ of the respondents. The farmer and members of the family often constitute the labour force which is grossly inadequate as observed by [20] that large scale agricultural production is impaired. But the problem is compounded where the young able-bodied men and women particularly the school leavers at all educational levels have developed a complete lack of interest in farming coupled with unattractive rural environment thereby resorting to migration into few urban centres in search of white-collar jobs that are not readily available [21]

Perhaps the most disturbing problem is the poor storage facilities which accounted for $(15.0 \%)$ of the respondents. It is true that farmers are producing but the storage facilities are grossly inadequate. It bothers on availability of the right technological facilities that could be employed for preserving the numerous agricultural products. As a developing country, this problem largely remains unaddressed as one would expect. Each year we lost many metric tonnes of yams, cassava, potatoes, grains, tomatoes, pepper, onions to poor storage facilities. The silos built across the country have not become operational!

Other problems identifies that are affecting agricultural development in the study area include of uncertainty weather condition which accounts for (14.0\%), price fluctuations $(11.5 \%)$ and high cost of transport $(11.0 \%)$. The issue of weather uncertainty, it is essentially a natural phenomenon which is often beyond the faculty of human reasoning. But with the Bakori Dam project, it is a right step in the right direction to harness surface water during the wet season and make it available for irrigation farming during the long dry season. The country needs more of such projects across Nigeria. Regarding fluctuations in market price, governments have failed in this direction to stabilize price of farm products. The colonial government set up Marketing Boards for industrial cash crops such as cocoa, palm produce, groundnuts and rubber neglecting food crops such as yam, cassava, maize, guinea corn which brought about acute shortage of food supply in the country till present [5]. The ugly situation has been the rising importation bill on food items which made Nigeria to become bankrupt to affluent countries.

\section{Policy Recommendations}

In this study, it has been shown that inequalities exist in varying degrees among the various local administrative units in Katsina State inspite of the national policy of building an egalitarian society. There is marked spatial variations among the unit areas in terms of agricultural development. The variables are dominated by Bakori, Funtua, and Sabuwa LGAs at the expense of other areas. The study revealed the notion of a polarized spatial pattern of agricultural development. The wetter areas tend to have more of the agricultural facilities than their average shares at the expense of the drier areas such as Danja, Faskari, Ijusawa and Fafur areas. [22] had earlier advocated for social justice, a policy of egalitarian society in which all government at all levels should embark on discriminatory investments in agriculturally backward areas with a bid to promote social justice and fair-play among all units that make up the country.

One can borrow the Brazilian experience that recognizes the significant role of the agricultural sector in ensuring sustainable economic development. The structure of the Brazilian agriculture paves way for the establishment of local processing of agricultural products for the home consumption as well as for export to other countries of the world (FAO, 2003). The federal government of Nigeria needs to actively promote the establishment of the agro-based industries that are capable of processing agricultural produce efficiently and effectively thereby creating more employment opportunities, boost real income of farmers and reduce wastes arising from poor storage facilities. 
The farmers at the community level suffer from differing shades of deprivation in terms of accessibility to farm inputs. More importantly, there is need for the provision of agricultural subsidies for agro-chemicals such as fertilizer, herbicides, insecticides, and farm equipment such as tractors that can enhance agricultural production. In addition, there is the need to put in place marketing institutions that would regulate the activities of the middle-men within the chain of distribution. Perhaps, it will not be out of place to restore the scrapped Marketing Board that will ensure imposition of agricultural tariff such that Nigeria's agricultural produce would be protected from illegal trading activities both at the national and internationally. (Daramola, 2004).

It is equally important to provide welfare package for the farmers that will form integral part of the policy to alleviate rural poverty and the redistribution of income in favour of the rural poor that constituted the majority. This laudable goal could be achieved by introducing agrarian reforms that geared towards improving the quality of rural life and this will go a long way not only to stem the tide of youth migration into the urban areas but also it will develop the much needed interest in agricultural activities.

TABLE 1: Socio-economic Characteristics of the Farmers.

\begin{tabular}{|c|c|c|c|}
\hline Variable & Category & Frequency & $\%$ \\
\hline \multirow[t]{4}{*}{ Age-group } & $0-20$ & 43 & 21.5 \\
\hline & $21-40$ & 68 & 34.0 \\
\hline & $41-60$ & 56 & 28.0 \\
\hline & Over 60 & 33 & 16.5 \\
\hline \multirow[t]{4}{*}{ Marital status } & Single & 35 & 17.5 \\
\hline & Married & 80 & 40.0 \\
\hline & Divorced & 39 & 19.5 \\
\hline & Widow & 46 & 23.0 \\
\hline \multirow[t]{4}{*}{ Level of income (p.a) } & $0-50,000$ & 26 & 13.0 \\
\hline & $51,000-100,000$ & 46 & 23.0 \\
\hline & $101,000-150,000$ & 53 & 26.5 \\
\hline & $151,000-200,000+$ & 75 & 37.5 \\
\hline \multirow[t]{4}{*}{ Farming experience (Yrs) } & $0-10$ & 31 & 15.5 \\
\hline & $11-20$ & 50 & 25.0 \\
\hline & $21-30$ & 67 & 33.5 \\
\hline & $31-40+$ & 52 & 26.0 \\
\hline \multirow[t]{4}{*}{ Level of education } & Non-formal education & 45 & 22.5 \\
\hline & primary & 75 & 37.5 \\
\hline & secondary & 63 & 31.5 \\
\hline & Quranic & 17 & 8.5 \\
\hline \multirow[t]{4}{*}{ Type of Agriculture } & Animal husbandry & 40 & 20.0 \\
\hline & Crop cultivation & 63 & 31.5 \\
\hline & Mixed farming & 45 & 22.5 \\
\hline & Horticulture & 52 & 26.0 \\
\hline
\end{tabular}

Source: Author

TABLE 2: Standardized Scores of LGAs in Agricultural Development.

\begin{tabular}{|c|c|c|c|c|c|c|c|c|c|}
\hline GAs & ZI & ZII & ZIII & ZIV & $\mathrm{ZV}$ & ZVI & ZVII & $\sum$ scores & Category \\
\hline Bakori & 1.51 & 1.43 & 0.81 & 1.29 & 1.10 & 1.13 & 1.20 & 8.47 & Upper Third \\
\hline Funtua & 0.19 & 1.13 & 1.58 & 0.71 & 1.52 & 1.25 & 1.01 & 7.39 & "6 \\
\hline Sabuwa & 1.27 & 0.71 & 0.25 & 1.25 & 1.15 & 1.29 & 1.25 & 7.17 & “6 \\
\hline Malunfashi & 0.35 & 1.21 & 1.09 & 1.16 & -0.06 & 0.83 & 1.51 & 6.09 & Middle Third \\
\hline Kankara & 1.10 & 1.35 & 1.24 & 0.29 & -0.65 & -0.31 & 1.23 & 4.25 & "6 \\
\hline Dandume & 0.92 & 0.72 & 0.18 & -0.25 & 0.52 & -0.45 & 0.85 & 2.49 & “ \\
\hline Danja & -0.45 & -0.31 & -0.62 & -0.70 & -0.58 & -0.19 & -0.31 & -3.16 & Bottom Third \\
\hline Faskari & -0.43 & -1.13 & -0.25 & -0.21 & -0.56 & -0.23 & -1.15 & -3.96 & “ \\
\hline Fafur & -0.39 & -0.90 & -0.59 & -0.38 & -0.62 & -0.35 & -0.85 & -4.08 & “ \\
\hline Ijusawa & -0.60 & -1.64 & -0.58 & -0.21 & -0.54 & -0.71 & -0.53 & -4.81 & “ \\
\hline
\end{tabular}

Source: Author

TABLE 3: Challenges of Agricultural Development $(\mathrm{N}=200)$

\begin{tabular}{|l|l|c|}
\hline Constraints & Frequency & $\%$ \\
\hline Weather uncertainty & 28 & 14 \\
\hline Rarity and high cost of agro-chemicals & 42 & 21 \\
\hline Shortage of farm labour & 30 & 15 \\
\hline High cost of transport & 22 & 11 \\
\hline Fluctuations in market price & 23 & 11.5 \\
\hline Poor storage facilities & 31 & 15.5 \\
\hline Activities of middle-men & 24 & 12 \\
\hline
\end{tabular}


Source: Author

\section{CONCLUDING REMARKS}

This study has attempted to bring into focus the level of development in agriculture in some selected local government areas in Katsina State of Nigeria and it becomes obvious that there is lopsidedness in agricultural development in terms of the distribution of the paraphernalia necessary for a meaningful growth and development within the sector. It is an open fact that the country cannot do without promoting this indispensable sector of the national economy and as such it must be accorded the recognition and attention it deserves. The study area is naturally endowed with rich loamy soil, favourable weather condition and cheap local labour. But the government needs to intervene in the area of rational planning to ensure equitable distribution of the equipment and farm inputs such that there could be some spatial balance in agricultural development not only within the study area but also in the country at large.

\section{References}

[1] Sanusi, L. S. (2010). Growth prospects for Nigerian economy. Governor of Central Bank of Nigeria (CBN). Lecture delivered at the $8^{\text {th }}$ Convocation at the Igbinedion University. Okada. Edo State. Nov. 26

[2] Ojo, M. O. (2004) Non-oils exports in Nigeria's changing policy dispensation. In central bank of Nigeria (CBN). Annual bulletin, $18: 2$

[3] Adefila, J. O. (2008). "Spatial variations in infrastructural development in Benue State". Savanna: Journal of environmental and social sciences. Ahmadu Bello University Press. Zaria. 21(1\&2):137-145

[4] Abayomi, F. (2006). An overview of Nigerian agricultural sectors. Journal of Agricultural Economic, 8(3), 7-16.

[5] Adefila, J. O. (2013). "Spatial effects of cocoa production on rural economy in Idanre-Ifedore area, Ondo State of Nigeria" Asian Journal of Agriculture and Rural Development (AJARD). 3(2):56-66. http://www.aessweb.com/journal..

[6] Daramola, B., (2004). 'Competitiveness of Nigerian Agriculture in a Global Economy: any Dividend(s) of Democracy?', Inaugural Lecture Series 36, delivered at the Federal University of Technology, Akure, Nigeria.

[7] Bola, O. (2007). Nigeria Agricultural sector. Oxford University press. Ibadan

[8] Ayoade, J. O. (2004). Introduction to climatology for the Tropics. Spectrum books. Ibadan, 220-230.

[9] Udo, R. K. (2001). Geographical regions of Nigeria. Oxford University press. Ibadan.

[10] Ettah, B. E., Akpan, O. D. and Etim, R. S. (2011). Effects of price and exchange rate fluctuations on Agricultural exports in Nigeria. International Journal of Economic development research and investment, 2(1), 2-10.

[11] Humbert, J. N. (2000) "The Multi-functional Role of Agriculture."Proceedings of the 7thWorld Sugar Conference. Durban:www.sugaronline.com/sugarindustry/index.htm.

[12] Manyong, V. M; Ikp, A; Olayem, J. K; Yusuf, S. A; Omona, B. T; Okoruwa, V,F. S; Idachaba, (2005). Agriculture in Nigeria: Identifying Opportunities for Increased Commercialization and Investment. USAID/IITA/UI. pp.1-190.

[13] Adefila, J. O. (2012). "Spatial assessment of farmers' cooperative organizations in agricultural development in Gurara area of Niger State, Nigeria". Journal of Ecology and Natural Environment (JENE). 4(2):51-57. Academic Journals. http://www.academicjournals.org/jene

[14] FAO (2003). Brazilian Rankings in Global Agricultural Commodity Production.https://www2.focusbrazil.org.br/siteus/reports/Industry\%20Reports/AGM.pdf (Lastaccessed March 24 2007).

[15] Ifabiyi, I. P. (2011). Spatial distribution and performance of water pumps in the rural areas of Kaduna State. Nigeria: Before the Second Republic. European Journal of Social Sciences. 26(1):15-25

[16] Aderamo, A. J. \& Aina, O. A. (2011). Spatial inequalities in social amenities in developing countries: A case from Nigeria. Australian Journal of Basic and Applied Science. 5(6):171-1

[17] Gollin, D. and Rogerson, R. (2002). The role of Agriculture in development. American Economic Review, 92(2), 160-170.

[18] Enoma, A. I. (2001). Long-run Agricultural growth in Nigeria: An empirical analysis. Journal of policy issues, 3(7), 10-2

[19] Akanji, O. and Ukeje, E. (2005). A review and analysis of Agricultural prices in Nigeria. In Central Bank of Nigeria (CBN), 33(4), $30-65$.

[20] Ajao, K. (2006). Cocoa development in Nigeria: The strategic role of national committee on development of cocoa. Presidential reports. Abuja

[21] Adefila, J. O. (2011). Changing patterns of migration and rural economic development in Igbomina area, Kwara State of Nigeria. Bayero Journal of social and management studies, 14(1), 120-131.

[22] Morenikeji, W. (2000). Dimension of development pattern in Nigeria: A spatial analysis" African Journal of social and policy studies. 1(2):144-151 